\title{
Trends and annual cycles in soundings of Arctic tropospheric ozone
}

\author{
Bo Christiansen $^{1}$, Nis Jepsen ${ }^{1}$, Rigel Kivi ${ }^{2}$, Georg Hansen ${ }^{3}$, Niels Larsen ${ }^{1}$, and Ulrik Smith Korsholm ${ }^{1}$ \\ ${ }^{1}$ Danish Meteorological Institute, Research and Development, Copenhagen, Denmark \\ ${ }^{2}$ Finnish Meteorological Institute, Arctic Research, Sodankylä, Finland \\ ${ }^{3}$ Norwegian Institute for Air Research, Fram Centre, Troms $\varnothing$, Norway \\ Correspondence to: Bo Christiansen (boc@dmi.dk)
}

Received: 7 April 2017 - Discussion started: 18 April 2017

Revised: 30 June 2017 - Accepted: 6 July 2017 - Published: 4 August 2017

\begin{abstract}
Ozone soundings from nine Nordic stations have been homogenized and interpolated to standard pressure levels. The different stations have very different data coverage; the longest period with data is from the end of the 1980s to 2014.

At each pressure level the homogenized ozone time series have been analysed with a model that includes both lowfrequency variability in the form of a polynomial, an annual cycle with harmonics, the possibility for low-frequency variability in the annual amplitude and phasing, and either white noise or noise given by a first-order autoregressive process. The fitting of the parameters is performed with a Bayesian approach not only giving the mean values but also confidence intervals.

The results show that all stations agree on a well-defined annual cycle in the free troposphere with a relatively confined maximum in the early summer. Regarding the low-frequency variability, it is found that Scoresbysund, Ny Ålesund, Sodankylä, Eureka, and Ørland show similar, significant signals with a maximum near 2005 followed by a decrease. This change is characteristic for all pressure levels in the free troposphere. A significant change in the annual cycle was found for Ny Ålesund, Scoresbysund, and Sodankylä. The changes at these stations are in agreement with the interpretation that the early summer maximum is appearing earlier in the year.

The results are shown to be robust to the different settings of the model parameters such as the order of the polynomial, number of harmonics in the annual cycle, and the type of noise.
\end{abstract}

\section{Introduction}

Tropospheric ozone is a short-lived trace gas with a lifetime of 3-4 weeks on average and a following strong temporal and spatial variability. Tropospheric ozone is dangerous to human health and crops. Furthermore, tropospheric ozone is a greenhouse gas - and therefore often characterized as a shortlived climate forcer or short-lived climate component - and the increase over the 20th century has led to a considerable positive (warming) radiative forcing only exceeded by that contributed by carbon dioxide and methane (Forster and Ramaswamy, 2007). Tropospheric ozone profiles from satellites have only been available for a decade; therefore, information about long-term trends and variability mainly comes from in situ measurements such as balloon soundings.

Tropospheric ozone originates from intrusions of stratospheric air or is produced in the troposphere itself by photochemical processes involving precursors such as nitrogen oxides. The precursors may be of natural origin or due to anthropogenic activities (see the review by Cooper et al., 2014). The sinks are photo-chemical processes and dry deposition at the surface. While the photo-chemical processes dominate globally, model studies (Wespes et al., 2012) indicate that in the Arctic anthropogenic pollution from the Northern Hemisphere is the dominant source of ozone from the surface to $400 \mathrm{hPa}$ and that the stratospheric influence is the main contribution at pressures less $400 \mathrm{hPa}$. The anthropogenic sources may either be formed in situ or transported to the site of reaction. In particular, summer emissions from fires in Russia and North America impact the tropospheric ozone in the Arctic. Nitrogen oxides are considered especially important in this respect, and apart from originating from anthropogenic activities they may also be 
formed in lightning processes (Cairo et al., 2010). The influx from the stratosphere may be caused by tropopause foldings as has been demonstrated using backwards trajectory calculations (Sørensen and Nielsen, 2001). Synoptic-scale processes as represented by the $250 \mathrm{hPa}$ geopotential height have also been successfully linked to the recent ozone increases in the lowermost stratosphere (Harris et al., 2008). Analysis of observations in the 2008 International Polar Year (Ancellet et al., 2016) indicates that stratosphere-troposphere exchange is larger over Greenland than over Canada.

In the 20th century, globally there has been a general increase in tropospheric ozone in qualitative agreement with the increasing levels of nitrogen oxides from pollution. In the last part of the 20th century ozone level stabilized over Europe and North America (Guicherit and Roemer, 2000); see also the reviews of Cooper et al. (2014) and Hartmann et al. (2013). A flattening of the trend is also seen in other regions over the last 10-15 years - although with many regional differences - and it is likely that this is at least partly due to the fact that the emission of precursors has been curbed (Oltmans et al., 2013). It should be noted that changes in tropospheric circulation patterns also may play a role (Lin et al., 2014).

In the Northern Hemisphere $(\mathrm{NH})$, tropospheric ozone peaks in the late spring or summer (e.g. Parrish et al., 2013; Cooper et al., 2014). The spring-summer peak is often attributed to enhanced photo-chemical production (Monks, 2000) and the latest occurring of the peak is often found in the most polluted continental regions. However, it has also been argued that the stratosphere-troposphere exchange may play a role.

There has been evidence found that the seasonal cycle of tropospheric ozone in the $\mathrm{NH}$ mid-latitudes has changed so that the peak now appears earlier than 20 years ago (Parrish et al., 2013). Parrish et al. (2013) finds in a study of five stations that the change in the peak occurrence is 3-6 days per decade since 1970. Cooper et al. (2014) extended the analysis including additional sites and confirmed that there is a general shift although not observed at all sites. Possible reasons for the changes in the seasonal cycle are changes in atmospheric patterns and emissions. Cooper et al. (2014) also called for additional analysis including e.g. the polar regions.

In the Arctic balloon soundings are relatively scarce and the measurement periods vary from station to station. The longest data series are from Resolute, Canada (Tarasick et al., 2005). In the European sector of the Arctic and over Greenland ozonesondes have been flown since late 1980s (Kivi et al., 2007). Accordingly, the reported long-term changes in tropospheric ozone are scattered. Logan et al. (1999) found decreasing tropospheric ozone at Resolute, Canada, in the period 1970-1996. Also, Fioletov et al. (1997) and Randel and Wu (1999) have reported ozone decreases at Resolute. Negative trends in tropospheric ozone over Canada in the period 1980-1993 were also reported by Tarasick et al. (1995) and Oltmans et al. (1998). Later, Tarasick et al. (2005) also noted that when the period 1991-2001 is considered the trends are positive. Oltmans et al. (2013) found for three stations in Arctic Canada that negative trends in the beginning of the period 1980-2010 had been neutralized by positive trends later in the period.

Kivi et al. (2007) studied the variations in ozone profiles using ozonesonde observations from seven northern highlatitude stations from 1989 to 2003. In the free troposphere they found a statistically significant increase of $11 \%$ in this period with largest values in January to April, the period of greatest inter-annual variability. They attributed the observed change to the combined increase in the stratospheretroposphere exchange and the transport of precursors towards the higher latitudes.

Here, we investigate ozone variability over nine northern high-latitude stations, with an emphasis on the measurements made over northern Europe and Greenland. We focus on the low-frequency variability and on the changes in the annual cycle for which previous results in the Arctic are scarce. The present study includes recent ozonesonde measurements obtained in the period from the early 2000s to 2014, which have not been analysed in details before. This results in a 27 -year data set for the longest record. We include ozonesonde data from Bear Island, Ørland, and Gardermoen that have not been considered in the previous studies of tropospheric ozone. The measurements are homogenized according to current recommendations. The ozone time series from the individual stations are analysed with a model, which includes both low-frequency variability and the annual cycle with higher harmonics. The potential for low-frequency variability is implemented both as a general polynomial trend and time-varying annual amplitudes and phases. The noise is either white or given by a first-order autoregressive process. The model is non-linear and may include a large number of parameters. The fitting of these parameters is performed with a Bayesian approach. The Bayesian approach gives us mean values and uncertainties not only of the parameters but also on derived quantities such as temporal differences and annual cycles. This approach naturally handles strongly irregular sampled time series including extended periods without data and is therefore favourable for the analysis of ozone time series.

\section{The data and method}

\subsection{Ozonesonde data}

The ozonesonde is an electrochemical device containing two electrode chambers: an anode chamber filled with potassium iodide saturated phosphate buffer and a cathode chamber filled with same phosphate buffer containing a well-defined concentration of potassium iodide (Kivi et al., 2007; Smit and the ASOPOS panel, 2014). During ascent through the atmosphere a constant volume pump is drawing atmospheric air through the cathode chamber. The content of ozone in an 
air sample is reacting with the potassium iodide and gives rise to a current proportional to the ozone amount. The electrode chambers and the pump is installed in a Styrofoam box for insolation purposes. To keep the buffer liquids from freezing during ascent, a simple heater element is keeping the temperature in box at $10-25^{\circ} \mathrm{C}$. A thermistor is sensing the actual temperature inside the box. On the outside of the Styrofoam box a regular radiosonde is mounted. The radiosonde is measuring pressure, temperature, humidity, wind speed, and wind direction during ascent. The ozone current and the box temperature is via an interface transmitted to a ground receiver along with the radiosonde parameters. The ozonesonde and the radiosonde are lifted with a helium or hydrogen filled meteorological balloon. At best the balloon may reach an altitude at $35-40 \mathrm{~km}$. The typical vertical resolution is around $10 \mathrm{~m}$ using $2 \mathrm{~s}$ intervals for sampling. However, the effective vertical resolution is of the order of 100$150 \mathrm{~m}$, given that the response time of the ozone sensor is $20-30$ s. Uncertainty of the ozone measurements by electrochemical sondes in the stratosphere is about 5\% (Deshler et al., 2008; Hassler et al., 2014).

Different types of ozonesondes have been in use over the years, the primary two types being manufactured by EnSci and Science Pump. Both types are constructed as described above. For each ozonesonde type there is a recommended composition of the anode and cathode solutions in use. Problems arise with a change to a different brand of ozonesonde. Such changes have taken place at all stations with the EnSci type becoming increasingly popular (see Fig. 2). Historically many launches have been made using a sensing solution recommended for Science Pump ozonesondes in case of switching to the use of EnSci type ozonesondes. To investigate the difference between the two sonde types and sensing solutions, a number of in situ measurements have been performed in the laboratory (Smit et al., 2007) and in the field (Kivi et al., 2007; Deshler et al., 2008). These measurements have resulted in the current recommendations for the ozonesonde preparations (Smit and the ASOPOS panel, 2014). In this work ozonesonde data were homogenized according to the recommended transfer functions for data homogenization (Deshler et al., 2017). A typical example of the conversion is from an EnSci sonde (e.g. of $1.0 \%$ sensing solution, $10 \mathrm{~g} \mathrm{~L}^{-1}$ ) to a Science Pump sonde of the same solution. In this case the conversion ratio is 0.96 for atmospheric pressures greater than $30 \mathrm{hPa}$, while it is $0.764+0.133 \log _{10}(p)$ for atmospheric pressures smaller than $50 \mathrm{hPa}$. Here, $p$ is the atmospheric pressure in $\mathrm{hPa}$. A similar formula describes the conversion between different sensing solutions. The Danish, Norwegian, and Finnish stations were homogenized by the authors of the present paper, while the data from Lerwick, Ny Ålesund, and Eureka were homogenized locally (see the Acknowledgements).

The geographic distribution of the included stations are shown in Fig. 1, and the covered time periods are summarized in Table 1. The number of soundings for each station

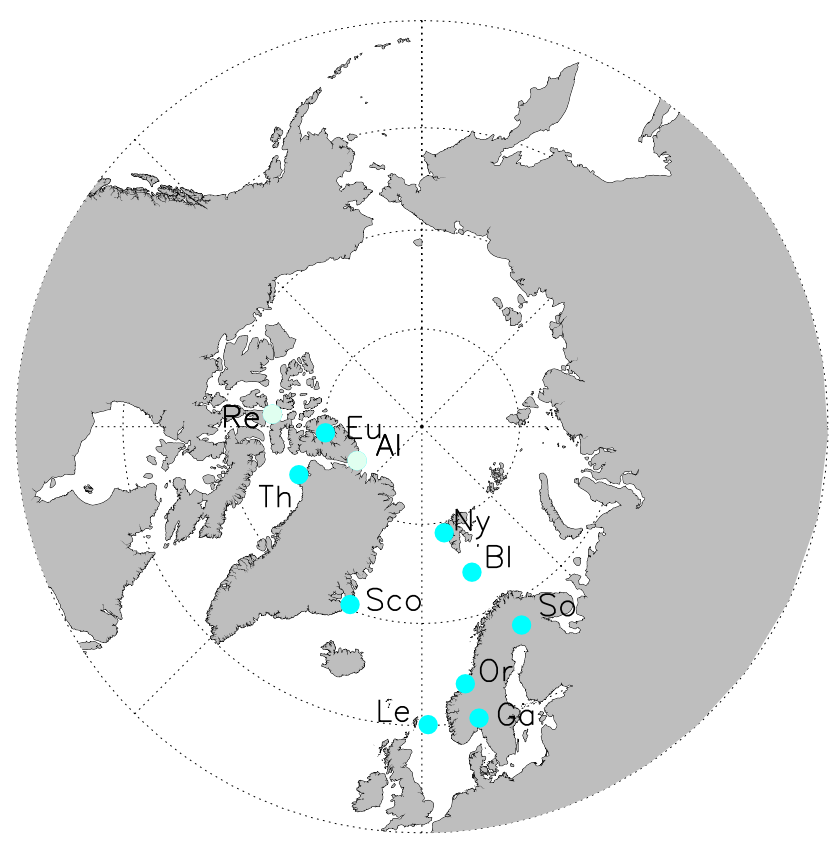

Figure 1. Geographical positions of the ozonesonde stations: Eureka (Eu), Ny ̊̊lesund (Ny), Thule (Th), Bear Island (BI), Scoresbysund (Sco), Sodankylä (So), Ørland (Or), Gardermoen (Ga), Lerwick (Le). Also, Resolute (Re) and Alert (Al) are shown.

as a function of year is shown in Fig. 2. This figure also shows the type of ozone sonde used. The longest time series span the period from the late 1980s to 2014. The time series of Bear Island, Gardermoen, and Ørland are particular brief spanning less than 10 years. In general the soundings are highly irregular timed with occasional years with very few or none soundings. We also note that the details vary a lot among the stations. The average yearly number of soundings are the largest (around 90) for Ny Ålesund and the lowest for Thule (around 20). There are in general more soundings in winter and spring than in summer and autumn (Table 1 shows the seasonal average of number of soundings disregarding years without soundings). This is due to the frequent ozonesonde campaigns to investigate the stratospheric vortex ozone depletion during the winter/spring season (Rex, 1993; von der Gathen et al., 1995; Manney et al., 2011). Two additional stations, Resolute and Alert, with long records have been studied. However, as these stations are close to Alert and show very similar behaviour, the results from these stations are shown in Figs. S2 and S3 in the Supplement.

For each station and for each homogenized ozone sounding, the ozone has been interpolated to standard pressure levels between 900 and $10 \mathrm{hPa}(900,800, \ldots 300,250, \ldots 100$, $80,70 \ldots 10 \mathrm{hPa}$.). The resulting ozone fields are shown as a function of time and pressure in Fig. 3 for each station. As expected there is a maximum on the lower stratosphere. Here and in the rest of the paper ozone partial pressure is measured in millipascal $(\mathrm{mPa})$. Time series of the free tro- 

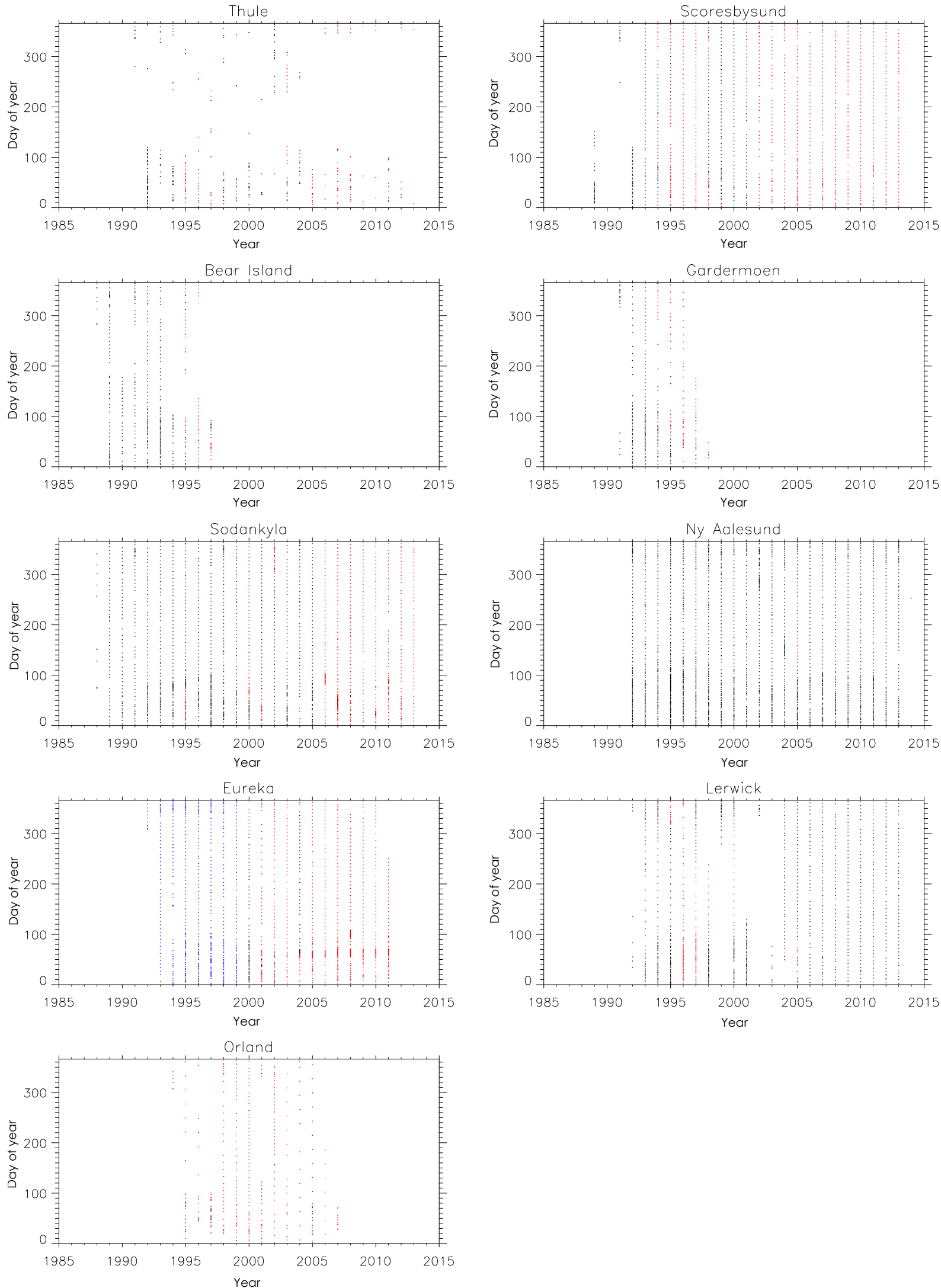

Figure 2. Timing of soundings. Each dot represents a sounding reaching at least $250 \mathrm{hPa}$. Red dots indicate EnSci type sondes and black dots Science Pump sondes. Blue dots indicate that the type is not reported in the records. 

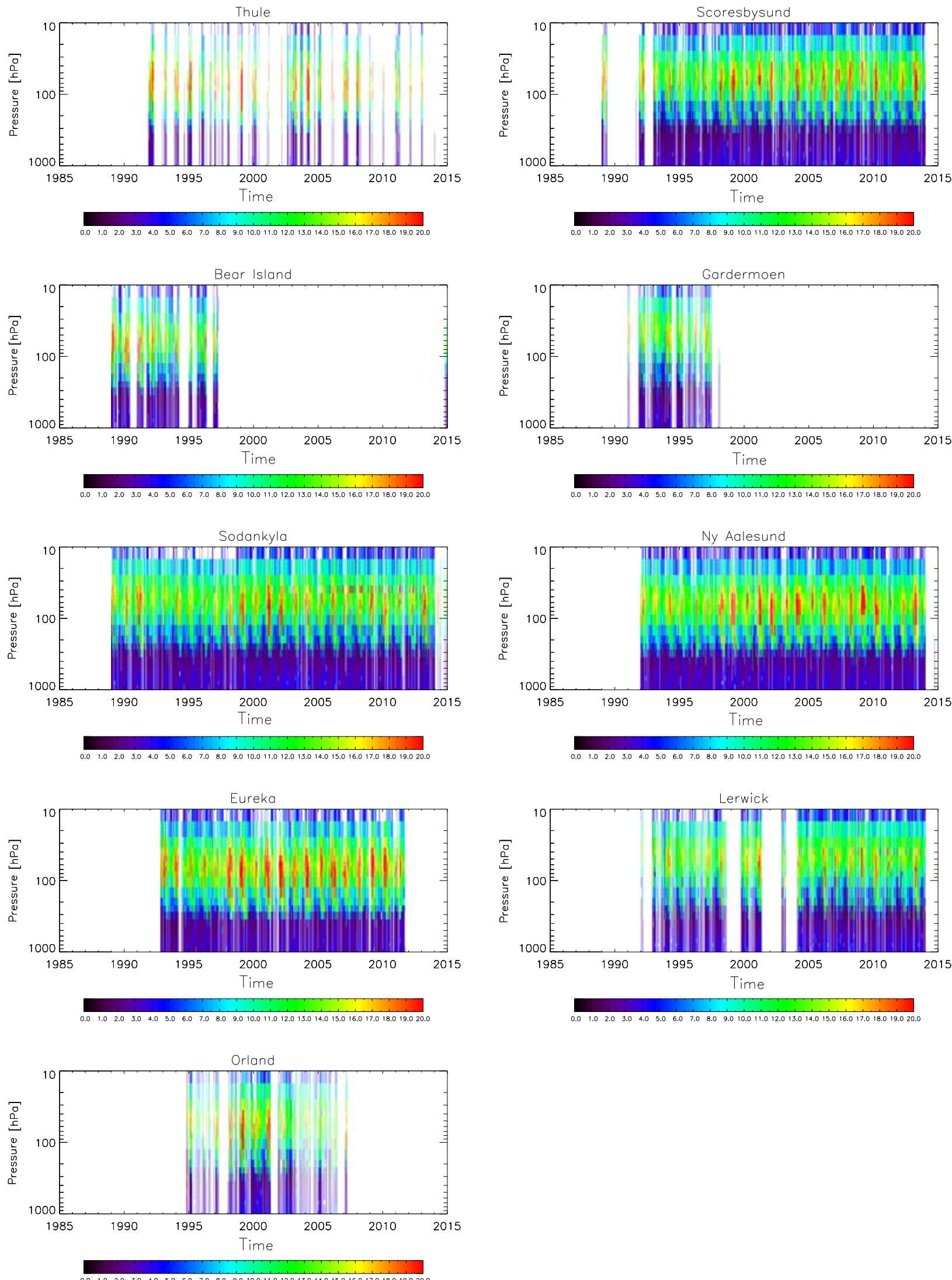

Figure 3. Ozone partial pressure $(\mathrm{mPa})$ as a function of time and pressure for the nine stations. 
Table 1. The stations included in the study. Results from Resolute and Alert are shown in the Supplement.

\begin{tabular}{lllll}
\hline Station name and country & Latitude & Longitude & Period & $\begin{array}{l}\text { Average no. soundings, whole year } \\
\text { winter/summer/spring/autumn }\end{array}$ \\
\hline Eureka (CA) & $80.1^{\circ} \mathrm{N}$ & $86.4^{\circ} \mathrm{W}$ & Nov 1992-Sep 2011 & 65 25/12/19/11 \\
Ny Ålesund (DE) & $78.9^{\circ} \mathrm{N}$ & $11.9^{\circ} \mathrm{E}$ & Jan 1992-Sep 2014 & $8834 / 15 / 26 / 15$ \\
Thule (Pituffik) (DK) & $76.5^{\circ} \mathrm{N}$ & $68.7^{\circ} \mathrm{W}$ & Oct 1991-Nov 2013 & 21 12/3/8/4 \\
Bear Island (N) & $74.3^{\circ} \mathrm{N}$ & $19.0^{\circ} \mathrm{E}$ & Oct 1988-Apr 1997 & $3915 / 9 / 14 / 8$ \\
Scoresbysund (DK) & $70.5^{\circ} \mathrm{N}$ & $22.0^{\circ} \mathrm{W}$ & Jan 1989-Dec 2013 & $5517 / 13 / 14 / 13$ \\
Sodankylä (FI) & $67.4^{\circ} \mathrm{N}$ & $26.7^{\circ} \mathrm{E}$ & Mar 1988-Dec 2013 & $6724 / 13 / 18 / 13$ \\
Ørland (N) & $63.7^{\circ} \mathrm{N}$ & $9.6^{\circ} \mathrm{E}$ & Nov 1994-Mar 2007 & $2510 / 5 / 8 / 5$ \\
Gardermoen (N) & $60.2^{\circ} \mathrm{N}$ & $11.1^{\circ} \mathrm{E}$ & Oct 1990-Feb 1998 & $3516 / 6 / 15 / 6$ \\
Lerwick (UK) & $60.1^{\circ} \mathrm{N}$ & $1.2^{\circ} \mathrm{W}$ & Feb 1992-Dec 2013 & $4919 / 10 / 14 / 12$ \\
Resolute (Ca) & $74.7^{\circ} \mathrm{N}$ & $95.0^{\circ} \mathrm{W}$ & Jan 1966-Dec 2015 & $4011 / 10 / 11 / 9$ \\
Alert (Ca) & $82.5^{\circ} \mathrm{N}$ & $62.3^{\circ} \mathrm{W}$ & Dec 1987-Dec 2013 & $4916 / 11 / 13 / 11$ \\
\hline
\end{tabular}

pospheric ozone at $500 \mathrm{hPa}$ are shown in Fig. 4 (black dots). Here, we already note that these ozone records show a background level of $2-4 \mathrm{mPa}$ and that the ozone records have large annual cycles and a considerable amount of scatter.

\subsection{Model description}

At each pressure level we want to model the temporal development of ozone. We are particularly interested in potential low-frequency trends, the annual cycle, and changes in the annual cycle. We therefore use a model that contains a trend, an annual cycle, and noise. The model has the form

$$
\begin{aligned}
y & =\lambda_{0}+\lambda_{1} t+\lambda_{2} t^{2}+\ldots a_{1} \sin \left(2 \pi t+\theta_{1}\right) \\
& +a_{2} \sin \left(2 \pi 2 t+\theta_{2}\right) \ldots+\xi
\end{aligned}
$$

where $y$ is the ozone and $t$ is the time (in years). Note that the amplitudes, $a_{i}$, and phases, $\theta_{i}$, may depend on time as detailed below.

The model has the following properties.

- The trend consists of a constant $\lambda_{0}$, a linear trend $\lambda_{1} t$, and higher-order polynomials up to $\lambda_{n_{\mathrm{pol}}-1} t^{n_{\mathrm{pol}}-1}$

- The annual cycle consist of a sum of $n_{\mathrm{cyc}}$ sinusoidals, $a_{i} \sin \left(2 \pi i t+\theta_{i}\right)$, with frequencies $1,2,3 \ldots n_{\mathrm{cyc}}$. The higher harmonics allow the seasonal cycle to be asymmetric. The amplitudes and phases of the cycles have trends with $n_{\mathrm{tr}}^{\mathrm{a}}$ and $n_{\mathrm{tr}}^{\theta}$ terms: $a_{i}=a_{i, 0}+a_{i, 1} t+$ $\ldots a_{i, n_{\mathrm{tr}}^{\mathrm{a}}} t_{\mathrm{tr}}^{\mathrm{a}}, \theta_{i}=\theta_{i, 0}+\theta_{i, 1} t+\ldots \theta_{i, n_{\mathrm{tr}}^{\theta}} t_{\text {tr. }}^{n_{\mathrm{tr}}}$. This allows the annual cycle to change over time.

- The noise is either independent Gaussian with variance $\sigma^{2}$ or an first-order autoregressive process (AR1) with coefficient $\theta$ and variance $\sigma^{2}$.

- Then, the model totally includes $2+n_{\mathrm{pol}}+n_{\mathrm{cyc}}\left(1+n_{\mathrm{tr}}^{\mathrm{a}}+\right.$ $\left.n_{\mathrm{tr}}^{\theta}\right)$ parameters under AR1 noise and one less under Gaussian noise.
The model is non-linear and includes a considerable number of parameters. The data (Fig. 2) are irregular samples with strong changes in the number of soundings over time but also with a strong seasonal cycle in the number of soundings. Calculating monthly or annual means followed by an estimation of the annual cycle and trends from these means - as done in some previous studies - is sub-optimal. It will, in particular, make the uncertainty difficult to estimate trustfully.

We therefore choose a Bayesian approach for interference (see e.g. Gelman et al., 2004). The Bayesian approach does not require regular temporally gridded data but can work directly with the original sampling. Bayesian approaches are becoming more frequent in many different areas of atmospheric and climate sciences (see e.g. Hasselmann, 1998; Berliner et al., 2000; Haslett et al., 2006; Huang et al., 2011; Tingley and Li, 2012; Aldrin et al., 2012; Christiansen, 2014; Olson et al., 2016). Probably the biggest difference between Bayesian and sequential methods is that in the Bayesian approach the parameters of the model can be seen as random variables and that this approach can systematically include prior information. More precisely, in the Bayesian approach a posterior distribution is calculated as the product of the likelihood of the data given the model and a prior distribution describing our previous knowledge of the parameters of the model. The posterior distribution includes all the wanted information, e.g. joint and marginal distributions of all the model parameter. Unfortunately, this information is not easily accessible as the posterior is not normalized and of high dimension (the number of parameters in the model). The posterior is therefore analysed by numerical methods. Here, this analysis is performed with a simple Metropolis-Hastings algorithm (Brooks et al., 2011). The Metropolis-Hastings algorithm is a Markov chain Monte Carlo method that obtains samples from the posterior, which can then be used to approximate the distribution.

This approach not only produces ensembles of all parameters but also of all derived quantities such as trends, annual 

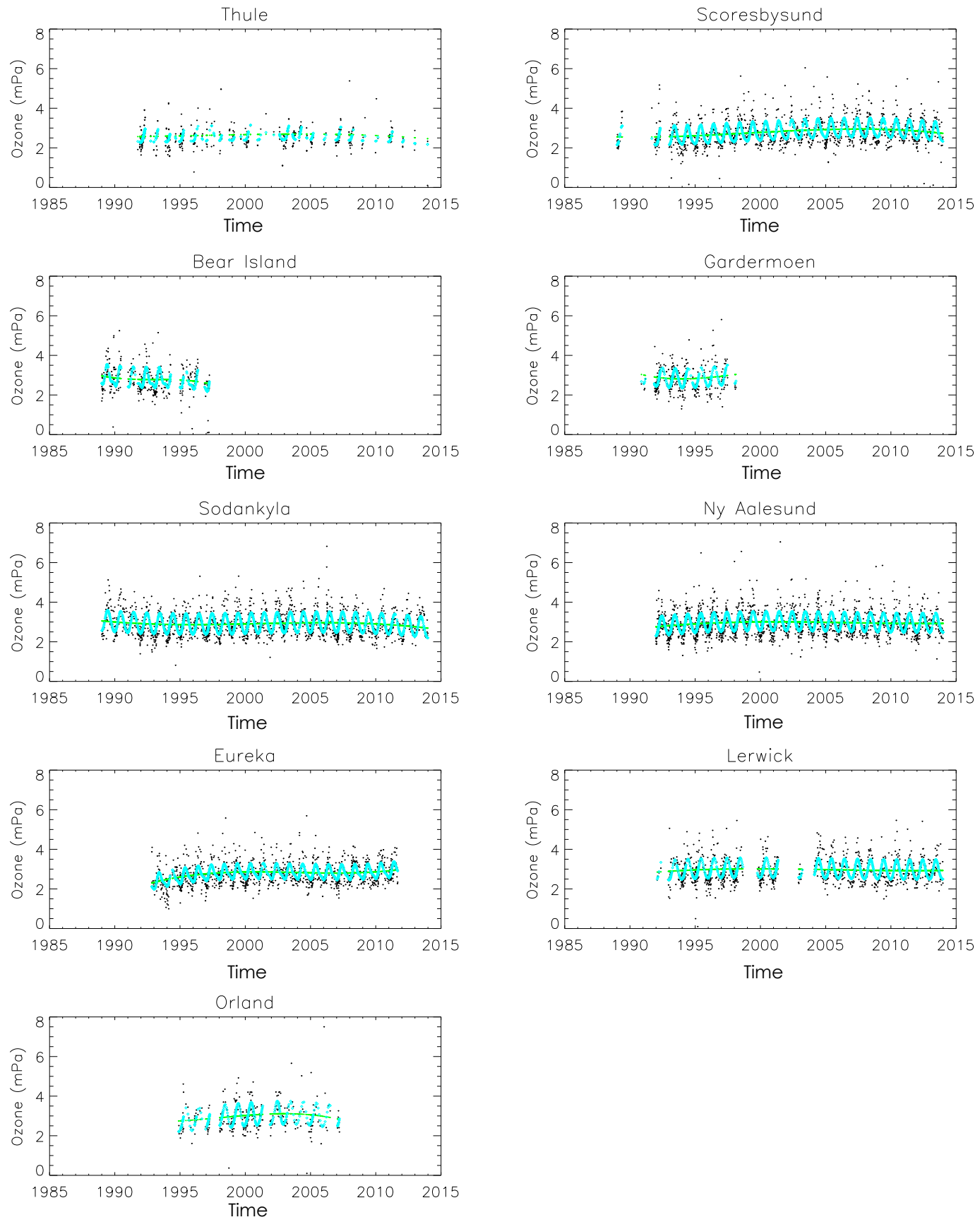

Figure 4. Ozone at $500 \mathrm{hPa}$ (partial pressure $\mathrm{mPa}$ ) for the nine stations. Observations (black), model mean fit (cyan), and polynomial part of the model (green) as a function of time at $500 \mathrm{hPa}$. Model settings: $n_{\mathrm{pol}}=4, n_{\mathrm{cyc}}=2, n_{\mathrm{tr}}^{\mathrm{a}}=n_{\mathrm{tr}}^{\theta}=0$, and white noise.

cycles, and changes in the annual cycles. These ensembles give the posterior distributions of the quantities under consideration and from these distributions we calculate and report the posterior mean and the $95 \%$ confidence intervals (or credible intervals as they are called in the Bayesian literature). Thus, this approach can provide mean and confidence intervals for, i.e. the difference of the annual cycle between two periods. We produce a large ensemble (20 000 members) of the posteriors and make sure that the process has converged. We discard the first half of the ensemble to avoid transients.

\section{Results}

Given the large differences in data coverage among the different stations, we can not expect that all station can pro- 

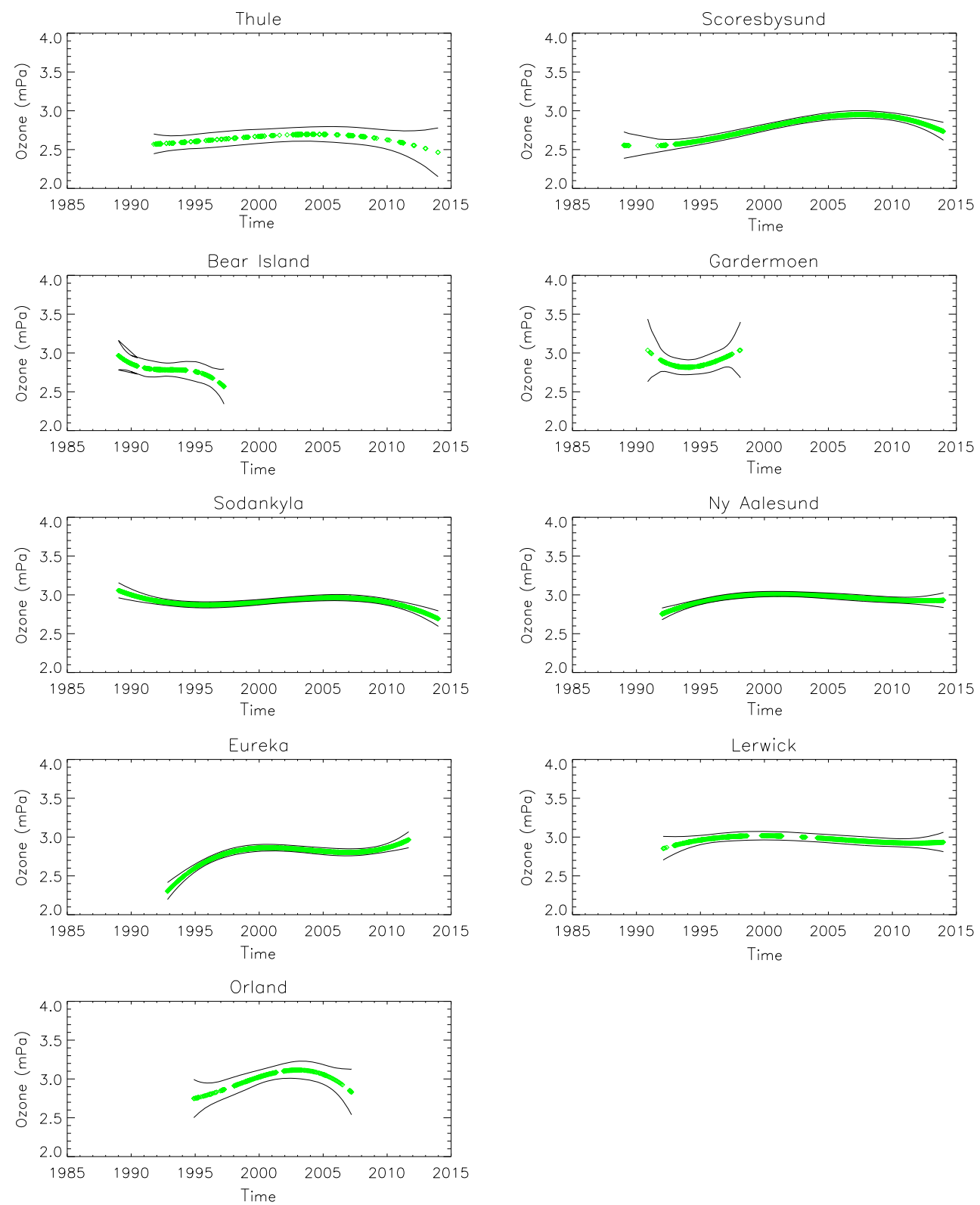

Figure 5. The polynomial part of the model as a function of time at $500 \mathrm{hPa}$. Green curve shows posterior mean, black curves indicate the $95 \%$ confidence intervals for each point in time. Model settings: $n_{\mathrm{pol}}=4, n_{\mathrm{cyc}}=2, n_{\mathrm{tr}}^{\mathrm{a}}=n_{\mathrm{tr}}^{\theta}=0$ and white noise.

vide sufficient information to constrain models with a high number of parameters. We therefore begin the analysis with a simple version of the model including only the polynomial trend and a fixed annual cycle. In Sect. 3.1 this model is used to study the long-term mean and the trends, and in Sect. 3.2 it is used to study the mean annual cycle. In Sect. 3.3 we extent the model to include trends in the amplitudes and phases of the annual cycle so that changes in the annual cycle can be studied. We only apply the extended model to the four stations with the best data coverage. In all subsections we begin by considering the $500 \mathrm{hPa}$ level before we proceed to other levels of the troposphere. As mentioned, the Bayesian approach gives not only point values but also the whole posterior distributions; therefore, we are able to produce confidence intervals for all the studied quantities.

\subsection{Mean and trends}

Figure 4 shows for each station at $500 \mathrm{hPa}$ the raw data (black points), the posterior mean of the non-stochastic part of the model, i.e. the polynomial part and the annual cycle (cyan), and the posterior mean of the polynomial part of the model (green) alone. The model includes a third-order polynomial $\left(n_{\mathrm{pol}}=4\right)$ and two components in the annual cycle $\left(n_{\mathrm{cyc}}=\right.$ 
2). The model does not include trends in the amplitudes and phases of the annual cycle and the noise is assumed white.

It is obvious that the Bayesian procedure has produced reasonable fits dominated by an annual cycle and including a weak inter-decadal variability. It is also obvious that there is a considerable residual scatter at all stations. This scatter is the expression of dynamical and chemical processes in the atmosphere as well as measurement noise. Residuals calculated as the difference between the mean model and the original data are shown in Fig. S2 for Ny Ålesund at $500 \mathrm{hPa}$. In the upper panel the residuals are shown as a function of time, the middle panel shows the residuals as a function of the day of the year, and the lower panel shows the histogram of the residuals. In general the residuals are stationary with little low-frequency structure. The distribution is approximately symmetric and not far from a Gaussian but with some outliers. There is no or only a weak seasonal cycle in the residuals. These results are characteristic for levels below $300 \mathrm{hPa}$ at all stations. Above $300 \mathrm{hPa}$ an annual cycle is seen in the residuals with the largest deviations in the winter. This is likely related to the strong stratospheric variability in this season. In particular at $300 \mathrm{hPa}$ the residuals are positively skewed, probably because this level moves in and out of the stratosphere. In the stratosphere the residuals are again almost Gaussian distributed.

Figure 5 shows both the mean polynomial part of the model (the cyan curve in Fig. 4) and its $95 \%$ confidence interval for each point in time at $500 \mathrm{hPa}$. For all stations the long-term background value is around $3 \mathrm{mPa}$ and the polynomial part is relatively flat with some weak low-frequency variability. The $95 \%$ confidence intervals are quite large relative to the low-frequency variability. This mainly reflects the data coverage but the confidence intervals also increases near the beginning and end of the time series where data are limited because of the asymmetry. For Scoresbysund, Sodankylä, Ny Ålesund, and Eureka some significant albeit weak low-frequency variability can be discerned. At Scoresbysund the ozone partial pressure increases until a maximum is reached near 2007 followed by a weak decrease. Ny Ålesund shows similar behaviour but now with the maximum around 2003. Sodankylä also shows a decrease in recent years with a maximum around 2005. However, Eureka shows a qualitative different variability with a strong increase from 1993 to 2000 followed by a quiet period until 2008 after which it again increases. The same behaviour is found for the nearby stations, Alert and Resolute (Figs. S2 and S3). At Thule, Bear Island, Gardermoen, and Lerwick no significant trends are found.

While the discussions above dealt with the $500 \mathrm{hPa}$ layer we now consider all layers in the troposphere. Figure 6 shows the long-term mean as a function of height. We see that the form of the vertical variations are identical for all stations. At the lowest level, $900 \mathrm{hPa}$, the mean ozone level is between 3 and $4 \mathrm{mPa}$ for all stations. The ozone content then decreases with height throughout the troposphere

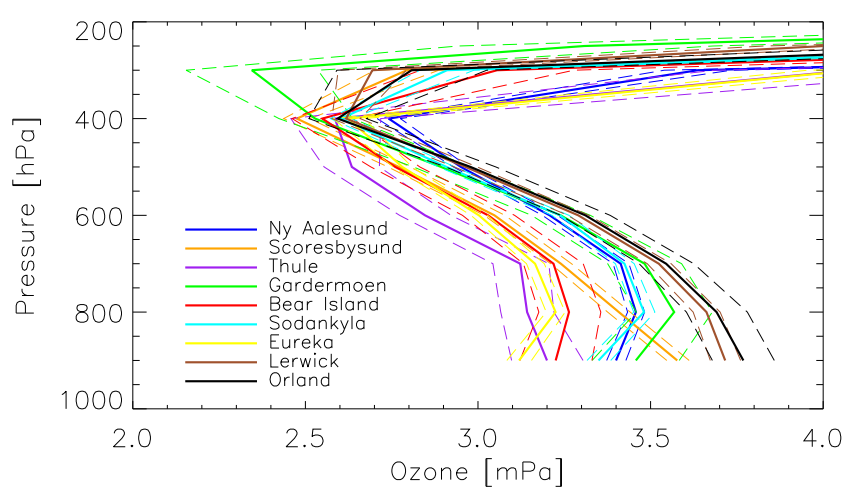

Figure 6. The long-term mean as a function of pressure (solid curves). Dashed curves indicate the $95 \%$ confidence intervals. Model settings: $n_{\mathrm{pol}}=4, n_{\mathrm{cyc}}=2, n_{\mathrm{tr}}^{\mathrm{a}}=n_{\mathrm{tr}}^{\theta}=0$, and white noise.

until a well-defined minimum of approximately $2.5 \mathrm{mPa}$ is reached around 300-400 $\mathrm{hPa}$. The ozone content then increases quickly with height when the stratosphere is reached. Note that in the troposphere it is discernible that stations at lowest latitude have larger ozone mixing ratios.

The contour plots in Fig. 7 show the anomalies at each level, i.e. the deviations from the long-term mean (the righthand plots in each panel show the long-term mean as in Fig. 6). Shaded areas indicates regions where the anomalies are significantly different from zero, i.e. where the ozone content can be considered different from the long-term mean. In agreement with the results at $500 \mathrm{hPa}$, we do not find much significant long-term variability at Thule, Bear Island, Gardermoen, and Lerwick. In particular for Bear Island and Gardermoen this might be connected to the brief span of the observations. At the other stations - Scoresbysund, Sodankylä, Ny Ålesund, Eureka, and Ørland - we find a consistent and significant signal throughout the troposphere. This signal in the troposphere has in general the same sign at all heights and values that decreases with the height. Except for Eureka there is a general agreement at these stations that a significant maximum was reached in the years around 2005 although the exact year of the maximum varies. At Eureka the ozone content increases after 2005, a result that is also found for Alert and Resolute (Figs. S2 and S3). Although the significance of the trends at Thule is weak, these trends also to some extent resemble those of Eureka pointing towards a distinct regional behaviour.

This is in general agreement with the discussion above about the variability at $500 \mathrm{hPa}$. The signal is weak or absent at the tropopause level but note also that a strong signal of the same sign as in the troposphere is found in the lower stratosphere. This might indicate that the low-frequency variability in the troposphere is linked to that of the stratosphere through dynamical processes. 

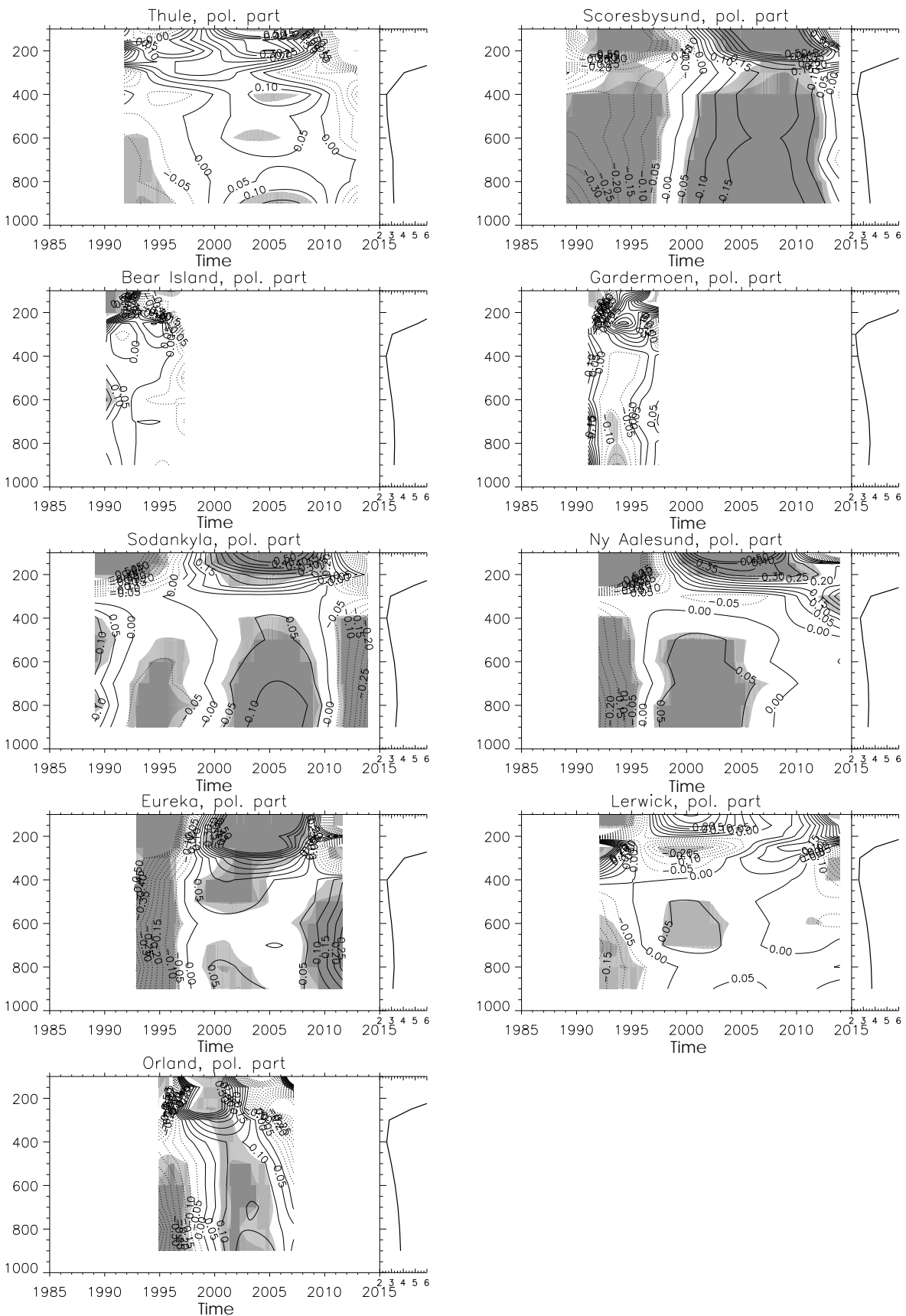

Figure 7. The polynomial part of the model as a function of time and pressure. The temporal means are shown in the panel to the right as a function of height. The contours show the anomalies with respect to this mean. Shaded regions are where the anomalies are statistically different from the temporal means at 99 and $95 \%$ levels. Model settings: $n_{\mathrm{pol}}=4, n_{\mathrm{cyc}}=2, n_{\mathrm{tr}}^{1}=n_{\mathrm{tr}}^{\theta}=0$ and white noise.

\subsection{Mean annual cycle}

For each station Fig. 8 shows both the mean annual cycle as well as the $95 \%$ confidence interval for each day of the year at $500 \mathrm{hPa}$. The annual cycle has a strong similarity for all stations. It has a minimum in winter, a maximum in early summer, and a peak-to-peak amplitude of approximately $1 \mathrm{mPa}$. We also note that the annual cycle would not be well modelled with a single sinusoidal as the early summer peak is more temporal confined than the winter minimum. The widths of the $95 \%$ confidence intervals reflect the data coverage and are largest for Thule, Gardermoen, Ørland, and Bear Island.

The mean annual cycle as a function of height is shown in Fig. 9 for each station. The annual cycle is rather similar for all stations consistent with the results for $500 \mathrm{hPa}$. For most 

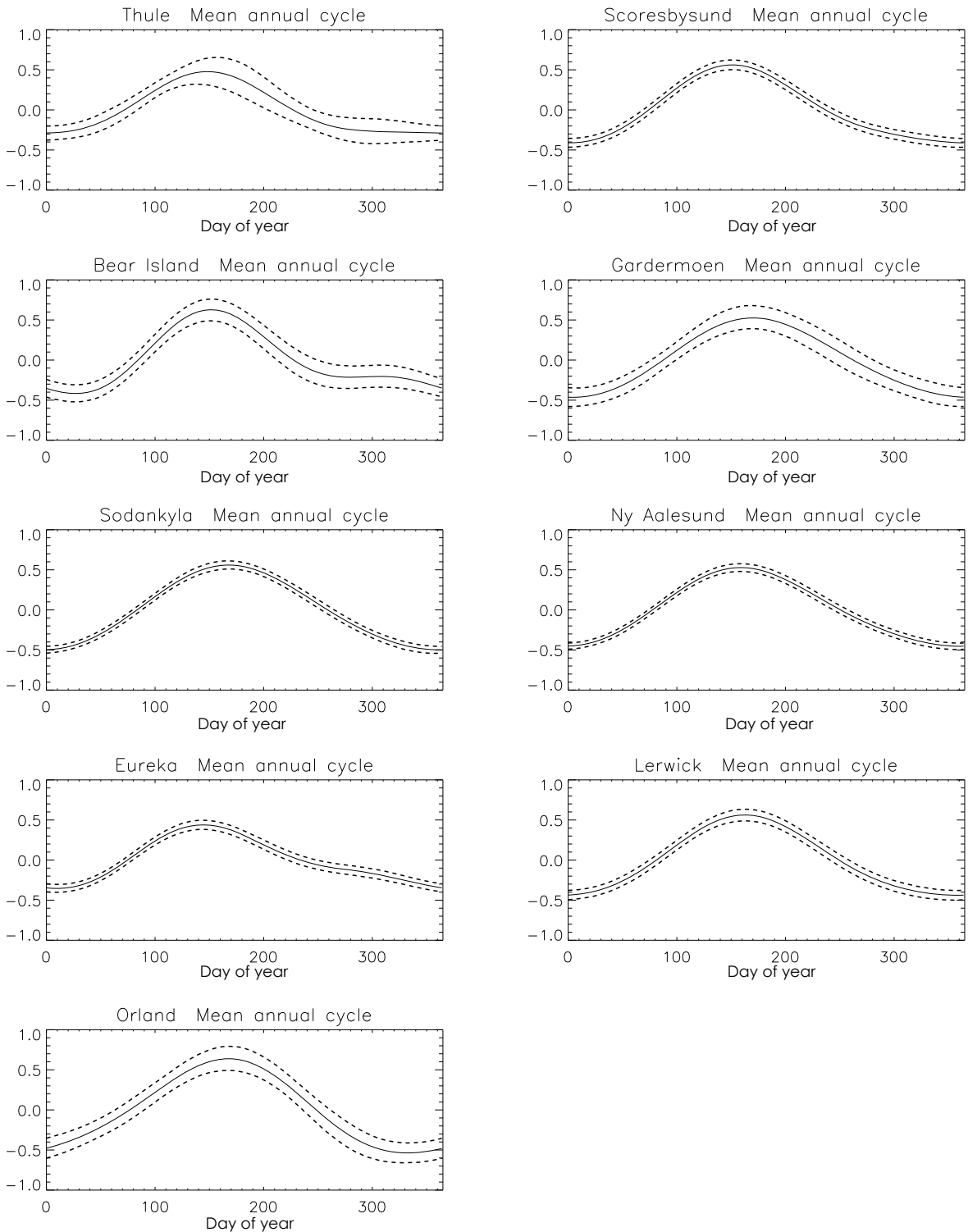

Figure 8. The annual cycle as a function of day of year at $500 \mathrm{hPa}$. The full curve shows the posterior mean; dashed curves indicate the $95 \%$ confidence intervals for each day of the year. Model settings: $n_{\mathrm{pol}}=4, n_{\mathrm{cyc}}=2, n_{\mathrm{tr}}^{1}=n_{\mathrm{tr}}^{\theta}=0$ and white noise.

stations there is a clear change of the phase of the annual cycle with height; the spring/summer maximum appears earlier at the lower levels than in the middle of the troposphere. This phase change is typically a couple of months. In the lower stratosphere the annual cycle again has the maximum earlier in the year. The amplitude of the annual cycle is relatively constant with height.

At the near surface at $900 \mathrm{hPa}$ there is some evidence for a qualitatively different annual cycle with a secondary maximum in autumn. This is observed for the most northern and eastern stations: Ny Ålesund, Thule, and Eureka. This is also found in the two additional Canadian stations, Alert and Resolute (Figs. S2 and S3).
As the sondes also record temperatures and heights, we can calculate the tropopause pressure for each sounding according to a lapse-rate criterion. Here we define the tropopause as the lowest height between 450 and $85 \mathrm{hPa}$, where the lapse rate drops below $2{ }^{\circ} \mathrm{C} \mathrm{km}^{-1}$. The annual cycle of the tropopause (monthly values) is included in Fig. 9 for the longest records: Scoresbysund, Sodankylä, Ny Ålesund, and Eureka. The general structure - high tropopause pressure in spring and low tropopause pressure in autumn is the same as reported in e.g. Zängl and Hoinka (2001). As expected the tropopause in general coincides with the levels where the vertical gradient in the ozone is largest. 

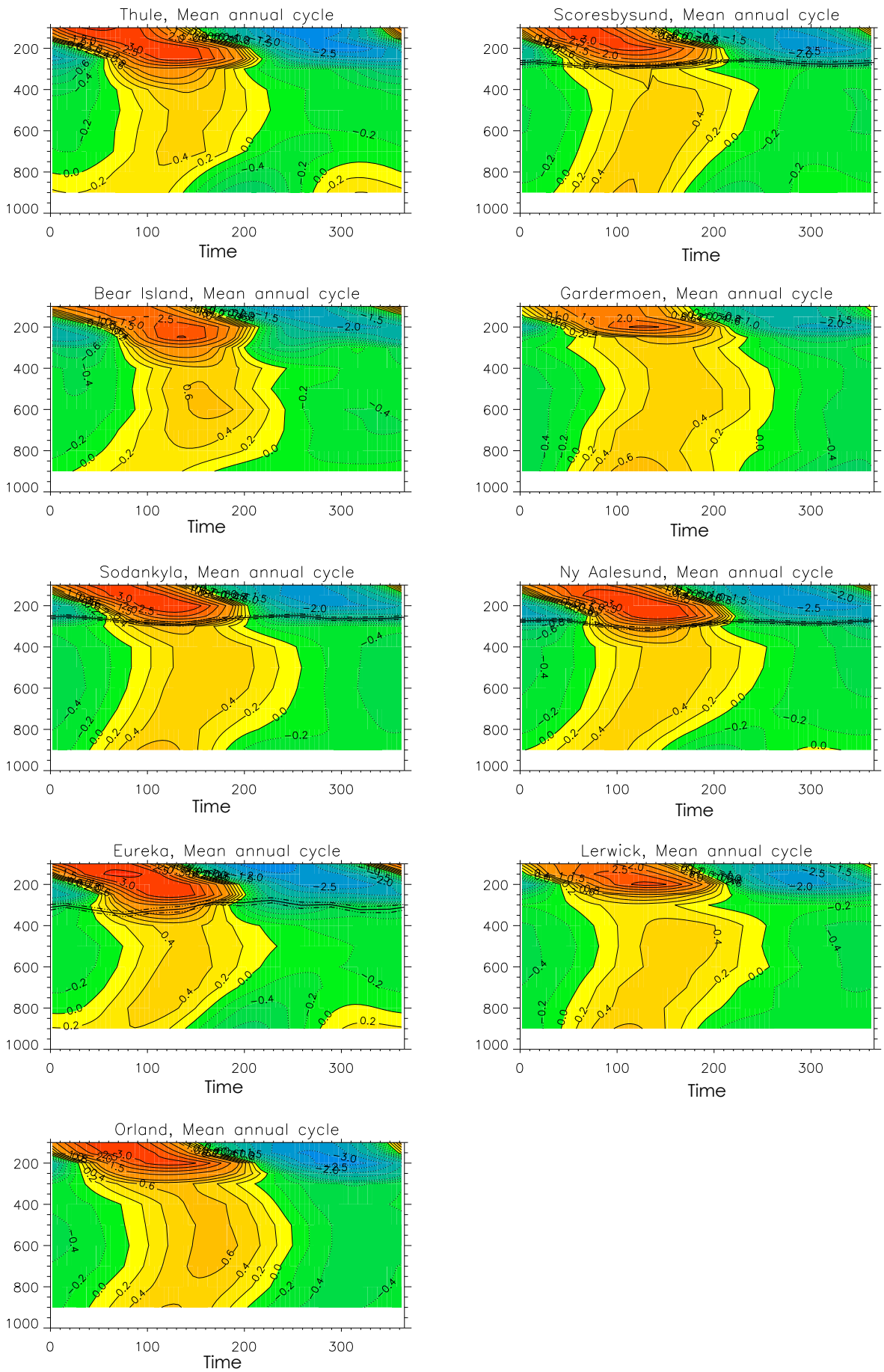

Figure 9. Mean annual cycle as a function of pressure level. Model settings: $n_{\mathrm{pol}}=4, n_{\mathrm{cyc}}=2, n_{\mathrm{tr}}^{\mathrm{a}}=n_{\mathrm{tr}}^{\theta}=0$, and white noise. For Scoresbysund, Sodankylä, Ny Ålesund, and Eureka the annual cycle of the tropopause is also shown (full black curve) together with its $\pm 2 \sigma$ confidence levels (dashed black curves).

Thus, one could speculate that at the lowest levels the annual cycle represents a combination of in situ processes and transport, while it in the upper parts of the troposphere (above $400 \mathrm{hPa}$ ) is related to the transport or dynamical effects from the stratosphere.

\subsection{Changes in the annual cycle}

We saw in the last section that the annual cycle was well modelled and almost identical for all stations. This provides some hope for that we have enough information to detect po- 

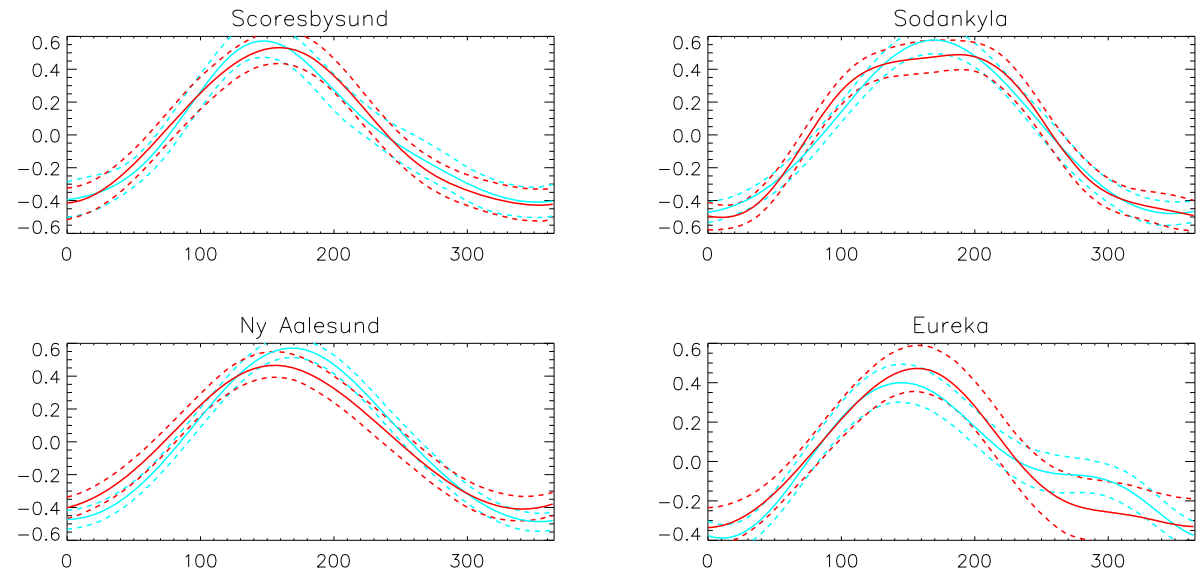

Figure 10. Average annual cycles over 1995-2000 (cyan) and 2007-2012 (red) at 500 hPa. Full curve is the posterior mean, dashed curves indicate the $95 \%$ confidence intervals. Model settings: $n_{\mathrm{pol}}=4, n_{\mathrm{cyc}}=3, n_{\mathrm{tr}}^{\mathrm{a}}=n_{\mathrm{tr}}^{\theta}=2$, and white noise.
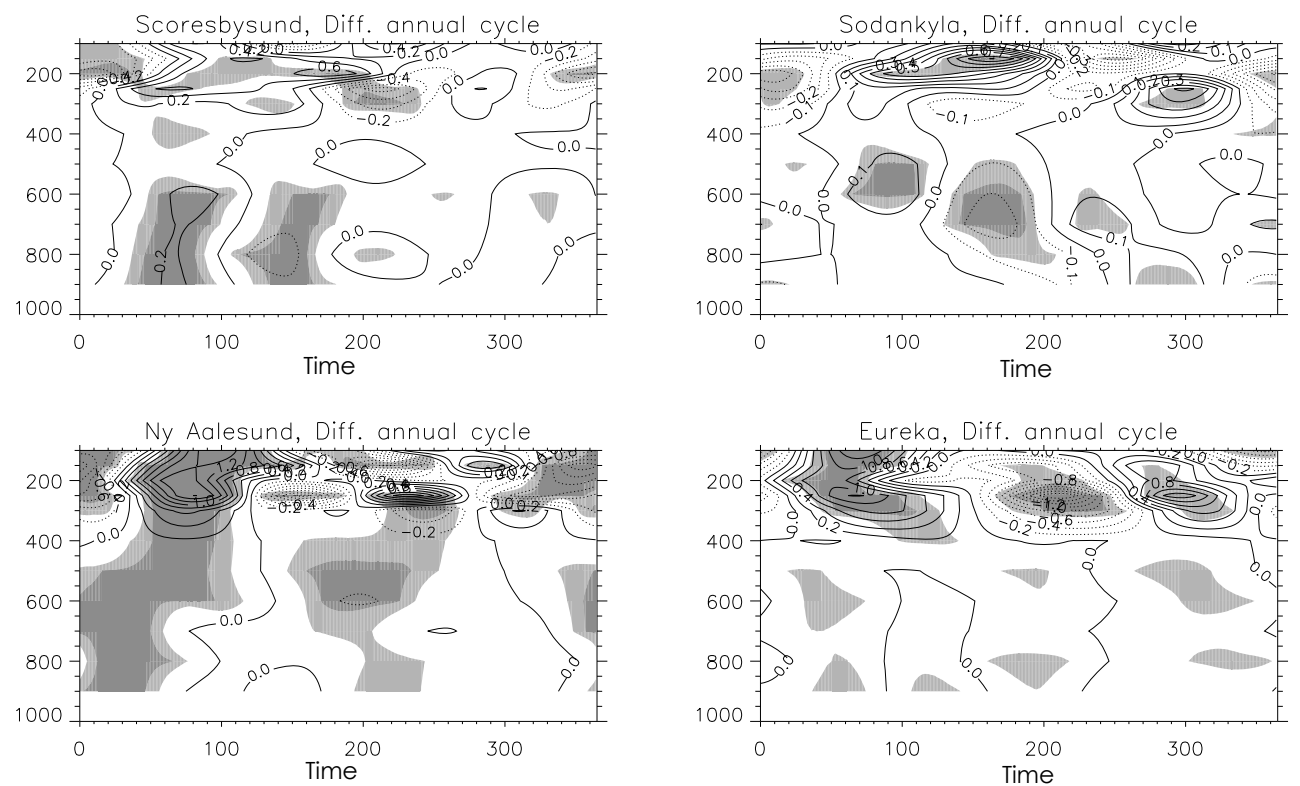

Figure 11. Difference between average annual cycles over 2007-2012 and 1995-2000 (i.e. average over 1995-2000 subtracted from average over 2007-2012) as a function of pressure level. Shaded regions are where the anomalies are statistically different from the temporal means at 99 and $95 \%$ levels. Model settings: $n_{\mathrm{pol}}=4, n_{\mathrm{cyc}}=3, n_{\mathrm{tr}}^{\mathrm{a}}=n_{\mathrm{tr}}^{\theta}=2$, and white noise.

tential changes in the annual cycle. We limit the following analysis to the four stations with best data coverage: Scoresbysund, Sodankylä, Ny Ålesund, and Eureka. We now extent the model from the last section by setting $n_{\mathrm{tr}}^{\mathrm{a}}=n_{\mathrm{tr}}^{\theta}=2$ and thereby allowing both the amplitudes and the phases of the annual cycle to vary in time like a second-order polynomial.

The results at $500 \mathrm{hPa}$ are shown in Fig. 10, where the annual cycles averaged over 1995-2000 and 2007-2012 are shown together with their $95 \%$ confidence intervals for each day of the year. It should be noted that there are large uncertainties connected to the changes in the annual cycles. The only significant change is found at Ny Ålesund, which shows a slight, significant decrease from 0.9 to 0.8 in the peak-topeak amplitude. There also seems to be a slight change in the phase with the maximum appearing a little (20 days) earlier in the later period. For the other stations there is very little and insignificant change in the amplitude and phase of the annual cycle at $500 \mathrm{hPa}$.

The differences between the mean annual cycles over 2007-2012 and 1995-2000 are shown as a function of pressure level in Fig. 11. The significant change found at Ny Alesund at $500 \mathrm{hPa}$ seems consistent with other levels in the troposphere for this station. Some significant changes are now also found for Scoresbysund and Sodankylä. These changes 

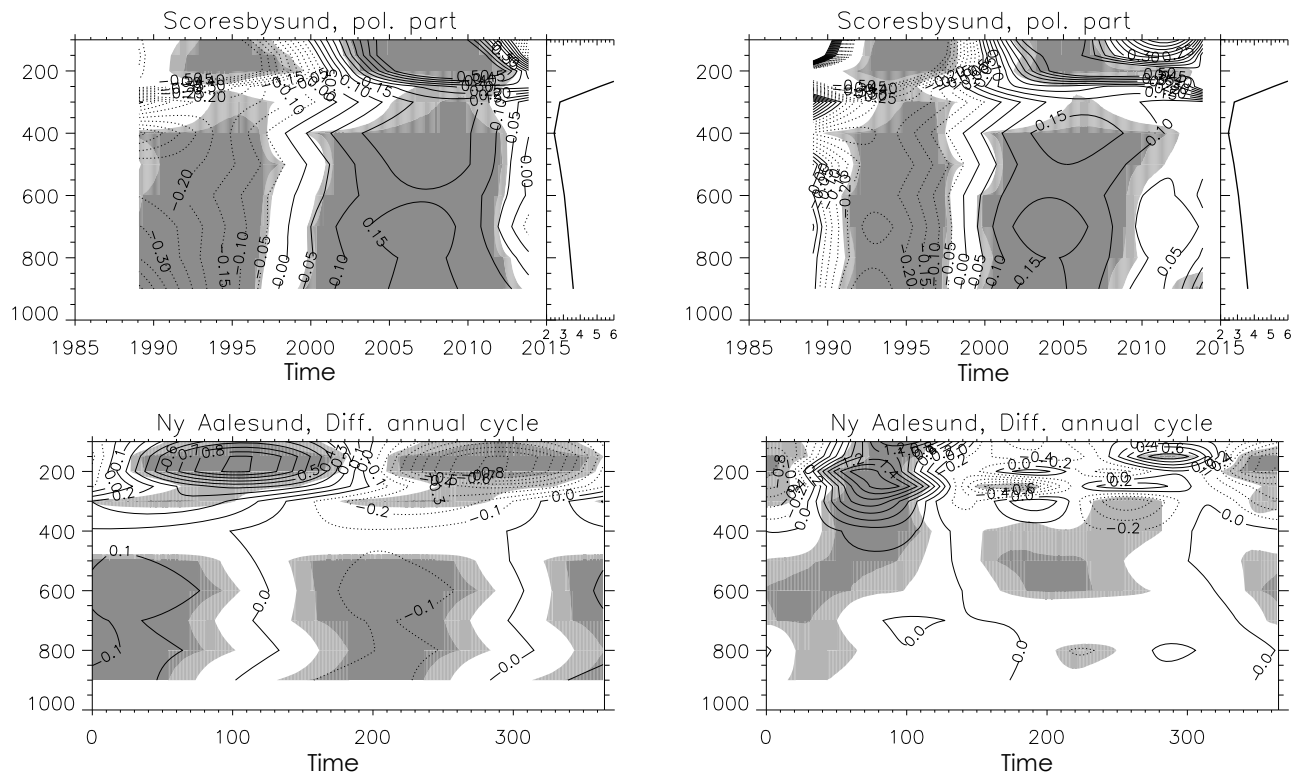

Figure 12. Top: the polynomial part of the model as a function of time and pressure for Scoresbysund. The models are $($ left $) n_{\text {pol }}=4$, $n_{\mathrm{cyc}}=3$, and $n_{\mathrm{tr}}^{\mathrm{a}}=n_{\mathrm{tr}}^{\theta}=2$, and white noise; (right) $n_{\mathrm{pol}}=5, n_{\mathrm{cyc}}=3$, and $n_{\mathrm{tr}}^{\mathrm{a}}=n_{\mathrm{tr}}^{\theta}=3$, and AR1 noise. Compare also to the top right plot in Fig. 7, which does not include trends in annual cycle $\left(n_{\mathrm{pol}}=4, n_{\mathrm{cyc}}=2, n_{\mathrm{tr}}^{1}=n_{\mathrm{tr}}^{\theta}=0\right.$ and white noise). Bottom: difference between average annual cycles over 1995-2000 and 2007-2012 as a function of pressure level for Ny Ålesund. Left: $n_{\text {pol }}=4, n_{\mathrm{cyc}}=1, n_{\mathrm{tr}}^{\mathrm{a}}=n_{\mathrm{tr}}^{\theta}=1$, and AR1 noise. Right: $n_{\mathrm{pol}}=5, n_{\mathrm{cyc}}=3, n_{\mathrm{tr}}^{\mathrm{a}}=n_{\mathrm{tr}}^{\theta}=3$, and AR1 noise. Compare also to the lower left panel in Fig. 11 .

consist of an amplification of the increasing spring branch of the annual cycle and weakening of the summer maximum. Thus, the changes in the annual cycles at Ny Ålesund, Scoresbysund, and Sodankylä have the same sign and patterns. Together this is consistent with the notion of the summer maximum appearing earlier in the year.

While the significance of the changes at Eureka are weak, the pattern of these changes agrees with the significant patterns found at Alert and Resolute (Figs. S2 and S3). For these stations the ozone levels in summer have increased and the autumn levels have decreased. As for the low-frequency variability (Sect. 3.1), this might point towards a distinct regional behaviour.

\section{Robustness of the results}

Our model allows for many different settings of the parameters and it is not obvious which setting that is the optimal choice. We have, for example, in the previous discussion restricted ourselves to model setups with white noise.

In this section we briefly discuss the robustness of the results to changes in the parameters of the model. We will restrict the presentation to Scoresbysund for the low-frequency variability and to Ny Ålesund for the changes in annual cycle, but similar results are found at other stations.

The upper panels in Fig. 12 show the polynomial part of the model for Scoresbysund as a function of height for model settings with either white noise or AR1 noise. The model settings also include trends in the annual cycle, which was not the case in Fig. 7. We observe that all three model settings agree on the shape of the low-frequency variability and, in particular, that they agree on the maximum obtained around the year 2005.

The lower panels in Fig. 12 show the difference in mean annual cycles over 2007-2012 and 1995-2000 for Ny Ålesund for two different settings, which include a different number of seasonal harmonics (also compare the bottom right panel in Fig. 11). We observe that all model settings agree on the pattern of the change in the annual cycle in the troposphere. Regarding the amplitude there are some smaller differences with the simplest model (fewest parameters) having the largest changes.

These results are typical for the stations with best data coverage. Some sensitivity is seen for stations with large gaps between soundings. It should also be noted that at the levels from $300 \mathrm{hPa}$ and above the residuals are strong and are positively skewed. This behaviour is probably due to the proximity to the stratosphere and the positive excursions related either to variation of the tropopause height or to intrusions of ozone-rich stratospheric air into the troposphere. 


\section{Conclusions}

We have analysed ozone long-term sounding records from nine Nordic stations. The different stations have very different data coverage. The longest period with data is from the end of the 1980s to 2014. The ozonesonde data were homogenized according to the recent, recommended transfer functions. We interpolated the homogenized series to standard pressure levels and in the following analysis we focused on the tropospheric levels. We applied a model that includes both a low-frequency variability in form of a polynomial, an annual cycle with harmonics, the possibility for low-frequency variability in seasonal amplitude and phasing, and noise that could be either white or a first-order autoregressive process. The fitting of the parameters were performed with a Bayesian approach giving not only the posterior mean values but also $95 \%$ confidence intervals. This approach is appropriate for strongly scattered data such as the ozone soundings. It can deal with data gaps and makes use of all the information in the data in contrast to methods based on producing monthly averages.

Our main findings are the following.

- The long-term averages have the same profile for all stations. The mixing ratios decrease with height from the largest values of 3-4 $\mathrm{mPa}$ at the lowest layer to a welldefined minimum around $400 \mathrm{hPa}$.

- All stations agree on a well-defined annual cycle in the free troposphere with a relatively confined maximum in the early summer. While the amplitude of the annual cycle does not vary much with height in the troposphere the spring/summer maximum appears somewhat (about 50 days) earlier in the lowest layers compared to the middle troposphere.

- Regarding the low-frequency variability, we find that Scoresbysund, Ny Ålesund, Sodankylä, Eureka, and Ørland show a consistent and significant structure with a maximum near 2005 followed by a decrease. This signal has the same sign for all heights and an amplitude that decreases with height. There is some evidence for a different regional signal at the Canadian stations with ozone levels increasing after 2005.

- Some changes in the annual cycle were found for Ny Ålesund, Scoresbysund, and Sodankylä with the most significant changes found for Ny Ålesund. The changes are consistent between the three stations - although there are differences in the vertical profile of the changes - and are in agreement with the notion of the summer maximum appearing earlier in the year.

- The results were shown to be robust to the different settings of the model parameters such as the order of the polynomial, number of harmonics in the annual cycle, and type of noise.
The significant maximum at Scoresbysund, Ny Ålesund, Sodankylä, Eureka, and Ørland around 2005 and the following decrease have not been reported before regarding observations in the free troposphere and the Arctic. Previous work (Kivi et al., 2007) covering data from 1989 to 2003 suggests a linear increase in the free troposphere of about $11 \%$ consistent with our observations for Thule, Scoresbysund, Ny Ålesund, Eureka, Sodankylä, and Ørland. Scoresbysund, Eureka, Ny Ålesund, and Sodankylä were also included in the study by (Kivi et al., 2007). The observed change was suggested to be due to changes in the Arctic Oscillation. Also, Tarasick et al. (2005) found positive trends for Canadian stations in the period 1991-2001 in contrast to the negative trends found when the longer period 1980-2001 is considered. Oltmans et al. (2013) did not find any overall trends in tropospheric ozone for three stations in the Canadian Arctic in the period 1980-2010; declines in the beginning of the period have rebounded. Here, we did not see any negative trends before the year 2001, except perhaps for the brief series at Bear Island.

Our finding that ozone peaks in spring/summer is in agreement with what is found for the NH (Parrish et al., 2013; Cooper et al., 2014). The change in the annual cycle so that the peak now appears earlier in the year has not been reported before for the Arctic but is in agreement with what is found for mid-latitudes (Parrish et al., 2013; Cooper et al., 2014), although significant changes are not found for all stations.

The decrease in Arctic tropospheric ozone since 2005 may be explained by the corresponding decrease in nitrogen oxide level observed in mid-latitude Europe, where current levels now are down to $50 \%$ of 1990 level (European Environment Agency, 2014). Nitrogen oxide is an important precursor for the production of tropospheric ozone, but this will still require transport of this species from Europe to the Arctic. Therefore, the change in free tropospheric ozone in the Arctic may reflect changes in both precursors and in transport, while possible changes in the stratosphere-troposphere exchange should be also considered.

Data availability. The ozone soundings can be downloaded from the World Ozone and UV database at Toronto (https://doi.org/10.14287/10000001, WMO/GAW Ozone Monitoring Community, 2017) and from the NDACC database (http://www.ndsc.ncep.noaa.gov/data/, NDACC, 2017)

\section{The Supplement related to this article is available online at https://doi.org/10.5194/acp-17-9347-2017-supplement.}

Competing interests. The authors declare that they have no conflict of interest. 
Special issue statement. This article is part of the special issue "Twenty-five years of operations of the Network for the Detection of Atmospheric Composition Change (NDACC) (AMT/ACP/ESSD inter-journal SI)". It does not belong to a conference.

Acknowledgements. We thank David Tarasick (Eureka), Peter von der Gathen (Ny Ålesund), and Dave Moore (Lerwick) for the ozone sounding data. This study was supported by the NMR KOL group (project no. NMR KOL 1402). Research at FMI was also supported by an EU Project GAIA-CLIM, the ESA's Climate Change Initiative programme and the Ozone_cci subproject in particular.

Edited by: Hal Maring

Reviewed by: two anonymous referees

\section{References}

Aldrin, M., Holden, M., Guttorp, P., Skeie, R. B., Myhre, G., and Berntsen, T. K.: Bayesian estimation of climate sensitivity based on a simple climate model fitted to observations of hemispheric temperatures and global ocean heat content, Environmetrics, 23, 253-271, 2012.

Ancellet, G., Daskalakis, N., Raut, J. C., Tarasick, D., Hair, J., Quennehen, B., Ravetta, F., Schlager, H., Weinheimer, A. J., Thompson, A. M., Johnson, B., Thomas, J. L., and Law, K. S.: Analysis of the latitudinal variability of tropospheric ozone in the Arctic using the large number of aircraft and ozonesonde observations in early summer 2008, Atmos. Chem. Phys., 16, 1334113358, https://doi.org/10.5194/acp-16-13341-2016, 2016.

Berliner, L. M., Wikle, C. K., and Cressie, N.: Long-lead prediction of Pacific SSTs via Bayesian dynamic modeling, J. Climate, 13, 3953-3968, 2000.

Brooks, S., Gelman, A., Jones, G., and Meng, X.-L.: Handbook of Markov Chain Monte Carlo: Methods and Applications, Chapman \& Hall, Boca Raton, 2011.

Cairo, F., Pommereau, J. P., Law, K. S., Schlager, H., Garnier, A., Fierli, F., Ern, M., Streibel, M., Arabas, S., Borrmann, S., Berthelier, J. J., Blom, C., Christensen, T., D'Amato, F., Di Donfrancesco, G., Deshler, T., Diedhiou, A., Durry, G., Engelsen, O., Goutail, F., Harris, N. R. P., Kerstel, E. R. T., Khaykin, S., Konopka, P., Kylling, A., Larsen, N., Lebel, T., Liu, X., MacKenzie, A. R., Nielsen, J., Oulanowski, A., Parker, D. J., Pelon, J., Polcher, J., Pyle, J. A., Ravegnani, F., Rivière, E. D., Robinson, A. D., Röckmann, T., Schiller, C., Simões, F., Stefanutti, L., Stroh, F., Some, L., Siegmund, P., Sitnikov, N., Vernier, J. P., Volk, C. M., Voigt, C., von Hobe, M., Viciani, S., and Yushkov, V.: An introduction to the SCOUT-AMMA stratospheric aircraft, balloons and sondes campaign in West Africa, August 2006: rationale and roadmap, Atmos. Chem. Phys., 10, 2237-2256, https://doi.org/10.5194/acp-10-2237-2010, 2010.

Christiansen, B.: Straight line fitting and predictions: On a marginal likelihood approach to linear regression and errors-in-variables models, J. Climate, 27, 2014-2031, 2014.

Cooper, O. R., Parrish, D. D., Ziemke, J., Balashov, N. V., Cupeiro, M., Galbally, I. E., Gilge, S., Horowitz, L., Jensen, N. R., Lamarque, J.-F., Naik, V., Oltmans, S. J.,
Schwab, J., Shindell, D. T., Thompson, A. M., Thouret, V., Wang, Y., and Zbinden, R. M.: Global distribution and trends of tropospheric ozone: An observation-based review, Elementa: Science of the Anthropocene, 2, 1-28, https://doi.org/10.12952/journal.elementa.000029, 2014.

Deshler, T., Mercer, J. L., Smit, H. G. J., Stubi, R., Levrat, G., Johnson, B. J., Oltmans, S. J., Kivi, R., Thompson, A. M., Witte, J., Davies, J., Schmidlin, F. J., Brothers, G., and Sasaki, T.: Atmospheric comparison of electrochemical cell ozonesondes from different manufacturers, and with different cathode solution strengths: The Balloon Experiment on Standards for Ozonesondes, J. Geophys. Res., 113, D04307, https://doi.org/10.1029/2007JD008975, 2008.

Deshler, T., Stübi, R., Schmidlin, F. J., Mercer, J. L., Smit, H. G. J., Johnson, B. J., Kivi, R., and Nardi, B.: Methods to homogenize electrochemical concentration cell (ECC) ozonesonde measurements across changes in sensing solution concentration or ozonesonde manufacturer, Atmos. Meas. Tech., 10, 2021-2043, https://doi.org/10.5194/amt-10-2021-2017, 2017.

European Environment Agency: Nitrogen oxides $\left(\mathrm{NO}_{x}\right)$ emissions, available at: http://www.eea.europa.eu/data-and-maps/ indicators/eea-32-nitrogen-oxides-nox-emissions- 1 (last access: 1 August 2017), 2014.

Fioletov, V. E., Kerr, J. B., Wardle, D. I., Davies, J., Hare, E. W., McElroy, C. T., and Tarasick, D. W.: Long-term ozone decline over the Canadian Arctic to early 1997 from ground-based and balloon observations, Geophys. Res. Lett., 24, 2705-2708, https://doi.org/10.1029/97GL52829, 1997.

Forster, P. and Ramaswamy, V.: Changes in Atmospheric Constituents and in Radiative Forcing, in: Climate Change 2007: The Physical Science Basis. Contribution of Working Group I to the Fifth Assessment Report of the Intergovernmental Panel on Climate Change, edited by Solomon, S., Qin, D., Manning, M., Chen, Z., Marquis, M., Averyt, K., Tignor, M., and Miller, H., chap. 2, Cambridge University Press, Cambridge, United Kingdom and New York, NY, USA, 2007.

Gelman, A., Carlin, J. B., Stern, H. S., and Rubin, D. B.: Bayesian data analysis, CRC press, second edn., Boca Raton, 2004.

Guicherit, R. and Roemer, M.: Tropospheric ozone trends, Chemosphere - Global Change Science, 2, 167-183, https://doi.org/10.1016/S1465-9972(00)00008-8, 2000.

Harris, N. R. P., Kyrö, E., Staehelin, J., Brunner, D., Andersen, S.B., Godin-Beekmann, S., Dhomse, S., Hadjinicolaou, P., Hansen, G., Isaksen, I., Jrrar, A., Karpetchko, A., Kivi, R., Knudsen, B., Krizan, P., Lastovicka, J., Maeder, J., Orsolini, Y., Pyle, J. A., Rex, M., Vanicek, K., Weber, M., Wohltmann, I., Zanis, P., and Zerefos, C.: Ozone trends at northern mid- and high latitudes - a European perspective, Ann. Geophys., 26, 1207-1220, https://doi.org/10.5194/angeo-26-1207-2008, 2008.

Hartmann, D., Klein Tank, A., Rusticucci, M., Alexander, L., Brönnimann, S., Charabi, Y., Dentener, F., Dlugokencky, E., Easterling, D., Kaplan, A., Soden, B., Thorne, P., Wild, M., and Zhai, P.: Observations: Atmosphere and Surface, in: Climate Change 2013: The Physical Science Basis. Contribution of Working Group I to the Fifth Assessment Report of the Intergovernmental Panel on Climate Change, edited by: Stocker, T., Qin, D., Plattner, G.-K., Tignor, M., Allen, S., Boschung, J., Nauels, A., Xia, Y., Bex, V., and Midgley, P., chap. 2, pp. 159-254, Cambridge University Press, 
Cambridge, United Kingdom and New York, NY, USA, https://doi.org/10.1017/CBO9781107415324.008, available at: www.climatechange2013.org (last access: 1 August 2017), 2013.

Haslett, J., Whiley, M., Bhattacharya, S., Salter-Townshend, M., Wilson, S. P., Allen, J. R. M., Huntley, B., and Mitchell, F. J. G.: Bayesian palaeoclimate reconstruction, J. Roy. Statist. Soc. Ser. A, 169, 395-438, 2006.

Hasselmann, K.: Conventional and Bayesian approach to climatechange detection and attribution, Q. J. Roy. Meteor. Soc., 124, 2541-2565, 1998.

Hassler, B., Petropavlovskikh, I., Staehelin, J., August, T., Bhartia, P. K., Clerbaux, C., Degenstein, D., Mazière, M. D., Dinelli, B. M., Dudhia, A., Dufour, G., Frith, S. M., Froidevaux, L., GodinBeekmann, S., Granville, J., Harris, N. R. P., Hoppel, K., Hubert, D., Kasai, Y., Kurylo, M. J., Kyrölä, E., Lambert, J.-C., Levelt, P. F., McElroy, C. T., McPeters, R. D., Munro, R., Nakajima, H., Parrish, A., Raspollini, P., Remsberg, E. E., Rosenlof, K. H., Rozanov, A., Sano, T., Sasano, Y., Shiotani, M., Smit, H. G. J., Stiller, G., Tamminen, J., Tarasick, D. W., Urban, J., van der A, R. J., Veefkind, J. P., Vigouroux, C., von Clarmann, T., von Savigny, C., Walker, K. A., Weber, M., Wild, J., and Zawodny, J. M.: Past changes in the vertical distribution of ozone - Part 1: Measurement techniques, uncertainties and availability, Atmos. Meas. Tech., 7, 1395-1427, https://doi.org/10.5194/amt-7-13952014, 2014.

Huang, Y., Leroy, S., and Goody, R. M.: Discriminating between climate observations in terms of their ability to improve an ensemble of climate predictions, P. Natl. Acad. Sci. USA, 108, 10405-10409, 2011.

Kivi, R., Kyrö, E., Turunen, T., Harris, N. R. P., von der Gathen, P., Rex, M., Andersen, S. B., and Wohltmann, I.: Ozonesonde observations in the Arctic during 19892003: Ozone variability and trends in the lower stratosphere and free troposphere, J. Geophys. Res., 112, D08306, https://doi.org/10.1029/2006JD007271, 2007.

Lin, M., Horowitz, L. W., Oltmans, S. J., Fiore, A. M., and Fan, S.: Tropospheric ozone trends at Mauna Loa Observatory tied to decadal climate variability, Nat. Geosci., 7, 136-143, https://doi.org/10.1038/ngeo2066, 2014.

Logan, J. A., Megretskaia, I. A., Miller, A. J., Tiao, G. C., Choi, D., Zhang, L., Stolarski, R. S., Labow, G. J., Hollandsworth, S. M., Bodeker, G. E., Claude, H., De Muer, D., Kerr, J. B., Tarasick, D. W., Oltmans, S. J., Johnson, B., Schmidlin, F., Staehelin, J., Viatte, P., and Uchino, O.: Trends in the vertical distribution of ozone: A comparison of two analyses of ozonesonde data, J. Geophys. Res., 104, 26373-26399, https://doi.org/10.1029/1999JD900300, 1999.

Manney, G. L., Santee, M. L., Rex, M., Livesey, N. J., Pitts, M. C., Veefkind, P., Nash, E. R., Wohltmann, I., Lehmann, R., Froidevaux, L., Poole, L. R., Schoeberl, M. R., Haffner, D. P., Davies, J., Dorokhov, V., Gernandt, H., Johnson, B., Kivi, R., Kyrö, E., Larsen, N., Levelt, P. F., Makshtas, A., McElroy, C. T., Nakajima, H., Parrondo, M. C., Tarasick, D. W., von der Gathen, P., Walker, K. A., and Zinoviev, N. S.: Unprecedented Arctic ozone loss in 2011, Nature, 478, 469-475, https://doi.org/10.1038/nature10556, 2011.

Monks, P. S.: A review of the observations and origins of the spring ozone maximum, Atmos. Environ., 34, 3545-3561, 2000.
NDACC: The ozonesonde data in the NDACC database, available at: http://www.ndsc.ncep.noaa.gov/data/, last access: $1 \mathrm{Au}-$ gust 2017.

Olson, R., Fan, Y., and Evans, J. P.: A simple method for Bayesian model averaging of regional climate model projections: Application to southeast Australian temperatures, Geophys. Res. Lett., 43, 7661-7669, https://doi.org/10.1002/2016GL069704, 2016.

Oltmans, S., Lefohn, A., Shadwick, D., Harris, J., Scheel, H., Galbally, I., Tarasick, D., Johnson, B., Brunke, E.-G., Claude, H., Zeng, G., Nichol, S., Schmidlin, F., Davies, J., Cuevas, E., Redondas, A., Naoe, H., Nakano, T., and Kawasato, T.: Recent tropospheric ozone changes - A pattern dominated by slow or no growth, Atmos. Environ., 67, 331-351, https://doi.org/10.1016/j.atmosenv.2012.10.057, 2013.

Oltmans, S. J., Lefohn, A. S., Scheel, H. E., Harris, J. M., Levy, H., Galbally, I. E., Brunke, E.-G., Meyer, C. P., Lathrop, J. A., Johnson, B. J., Shadwick, D. S., Cuevas, E., Schmidlin, F. J., Tarasick, D. W., Claude, H., Kerr, J. B., Uchino, O., and Mohnen, V.: Trends of ozone in the troposphere, Geophys. Res. Lett., 25, 139-142, https://doi.org/10.1029/97GL03505, 1998.

Parrish, D. D., Law, K. S., Staehelin, J., Derwent, R., Cooper, O. R., Tanimoto, H., Volz-Thomas, A., Gilge, S., Scheel, H.-E., Steinbacher, M., and Chan, E.: Lower tropospheric ozone at northern midlatitudes: Changing seasonal cycle, Geophys. Res. Lett., 40, 1631-1636, https://doi.org/10.1002/grl.50303, 2013.

Randel, W. J. and Wu, F.: Cooling of the Arctic and Antarctic polar stratospheres due to ozone depletion, J. Climate, 12, 1467-1479, https://doi.org/10.1175/15200442(1999)012<1467:COTAAA>2.0.CO;2, 1999.

Rex, M.: Stratosphärische Ozonabbauraten aus den Ozonsondendaten der EASOE-Kampagne im Winter 1991/92, PhD thesis, Diplom thesis, Georg-August-Universität zu Göttingen, 1993.

Smit, H. G. J. and the ASOPOS panel: Quality assurance and quality control for ozonesonde measurements in GAW, Tech. Rep. GAW Report \#201, Assessment of Standard Operating Procedures for Ozonesondes, World Meteorological Organization, Geneva, Switzerland, 2014.

Smit, H. G. J., Straeter, W., Johnson, B. J., Oltmans, S. J., Davies, J., Tarasick, D. W., Hoegger, B., Stubi, R., Schmidlin, F. J., Northam, T., Thompson, A. M., Witte, J. C., Boyd, I., and Posny, F.: Assessment of the performance of ECC-ozonesondes under quasi-flight conditions in the environmental simulation chamber: Insights from the Juelich Ozone Sonde Intercomparison Experiment (JOSIE), J. Geophys. Res., 112, D19306, https://doi.org/10.1029/2006JD007308, 2007.

Sørensen, J. and Nielsen, N.: Intrusion of stratospheric ozone to the free troposphere through tropopause folds - a case study, Phys. Chem. Earth Pt. B, 26, 801-806, https://doi.org/10.1016/S14641909(01)00088-0, 2001.

Tarasick, D. W., Wardle, D. I., Kerr, J. B., Bellefleur, J. J., and Davies, J.: Tropospheric ozone trends over Canada: 1980-1993, Geophys. Res. Lett., 22, 409-412, https://doi.org/10.1029/94GL02991, 1995.

Tarasick, D. W., Fioletov, V. E., Wardle, D. I., Kerr, J. B., and Davies, J.: Changes in the vertical distribution of ozone over Canada from ozonesondes: 1980-2001, J. Geophys. Res., 110, D02304, https://doi.org/10.1029/2004JD004643, 2005. 
Tingley, M. P. and Li, B.: Comments on "Reconstructing the NH mean temperature: Can underestimation of trends and variability be avoided?", J. Climate, 25, 3441-3446, 2012.

von der Gathen, P., Rex, M., Harris, N. R. P., Lucic, D., Knudsen, B. M., Braathen, G. O., De Backer, H., Fabian, R., Fast, H., Gil, M., Kyrö, E., Mikkelsen, I. S., Rummukainen, M., Stähelin, J., and Varotsos, C.: Observational evidence for chemical ozone depletion over the Arctic in winter 1991-92, Nature, 375, 131-134, https://doi.org/10.1038/375131a0, 1995.

Wespes, C., Emmons, L., Edwards, D. P., Hannigan, J., Hurtmans, D., Saunois, M., Coheur, P.-F., Clerbaux, C., Coffey, M. T., Batchelor, R. L., Lindenmaier, R., Strong, K., Weinheimer, A. J., Nowak, J. B., Ryerson, T. B., Crounse, J. D., and Wennberg, P. O.: Analysis of ozone and nitric acid in spring and summer Arctic pollution using aircraft, ground-based, satellite observations and MOZART-4 model: source attribution and partitioning, Atmos. Chem. Phys., 12, 237-259, https://doi.org/10.5194/acp12-237-2012, 2012.
WMO/GAW Ozone Monitoring Community: World Meteorological Organization-Global Atmosphere Watch Program (WMO-GAW)/World Ozone and Ultraviolet Radiation Data Centre (WOUDC) [Data], available at: https://doi.org/10.14287/10000001, last access: 1 August 2017.

Zängl, G. and Hoinka, K. P.: The tropopause in the polar regions, J. Climate, 14, 3117-3139, 2001. 